\title{
A LITERATURE REVIEW STUDY OF THE RELATIONSHIP BETWEEN LEADERSHIP STYLE, LEADERSHIP BEHAVIOUR, AND LEADERSHIP TRAITS
}

\author{
Wael Ibrahim Alsarrani ${ }^{*}$, Ahmad Jusoh ${ }^{2}$, Ayman Ahmed Alhaseri ${ }^{3}$, Amani Almeharish ${ }^{4}$ \\ ${ }^{1 *}$ Prince Sultan Armed Forces Hospital Madinah, Ad Difa district, Medina 42375 Saudi Arabia; ${ }^{2}$ Azman Hashim \\ International Business School, Universiti Teknologi Malaysia, Malaysia; ${ }^{3}$ Ministry of education, Saudi Arabia; ${ }^{4}$ King \\ Faisal Specialist Hospital \& Research Center, Saudi Arabia. \\ Email: ${ }^{1 *}$ drwaelalsarrani@ outlook.sa, ${ }^{2}$ ahmadj@utm.my, ${ }^{3}$ hasri.ayman@ gmail.com, ${ }^{4}$ aalmeharish26@kfshrc.edu.sa
}

Article History: Received on $2^{\text {nd }}$ March 2021, Revised on 22 $2^{\text {nd }}$ July 2021, Published on $12^{\text {th }}$ August 2021

\begin{abstract}
Purpose: This paper attempts to interpret and discuss leadership and the three contradicted terms to reveal the misuse of those three terms with leadership.

Methodology: The study uses a systematic method to review the previous literature related to the leadership domain and the three contradicted terms related to leadership. These are leadership style, leadership behaviour, and leadership traits. In addition, this study provides the definitions of the three contradicted terms from a linguistic and management literature perspective.
\end{abstract}

Main Findings: The study proposed a definition of each of the three contradicted terms. Additionally, the study suggested a conceptual framework that combined how the three contradicted terms can be related. The findings will contribute to the expansion of theoretical knowledge in the field of leadership.

Applications of this study: This paper indicates that the review of the literature regarding what differentiates the three contradicted terms is an important aspect to deeply understand leadership concepts. The definition of each of the three contradicted terms will expand the understanding of junior leadership researchers and university students.

The study's originality: This study will reveal the ambiguity and misinterpretation in the literature regarding the three contradicted terms of leadership. Moreover, it will present the definition of each of the three terms; leadership style, leadership behaviour, and leadership traits. Furthermore, the proposed conceptual framework will contribute to the expansion of theoretical knowledge in the leadership domain.

Keyword: Leadership Definitions, Systematic Literature Review, Interactive Linguistic and Leadership Review.

\section{INTRODUCTION}

Leadership concept is considered as one of the most complex and challenging concepts (Alblooshi, Shamsuzzaman, \& Haridy, 2020, Ford, \& Polin, 2021; Sousa \& van Dierendonck, 2021; Uhl-Bien, 2021) in the management study as general and the trait research as specific (Chemers, 2014; Laohavichien, Fredendall, \& Cantrell, 2009; Stewart, 2006). Management studies concentrate on how leaders influence followers for better organisational performance. This view of leadership is process-based. In contrast, the concentration of the traits research concerns the characteristics, traits, and behaviours of effective leaders. The traits research views leadership as individual-based (Freedman, 2016; Horner, 1997).

The rationale behind the leader complexity and significance is their role in influencing subordinates where leader and subordinates are combined (Alblooshi et al., 2020; Uhl-Bien, 2021). This role of a leader's ability to influence subordinates has developed gradually over the past 50 years (Laohavichien et al., 2009). For instance, there are many examples of leader ability illustrated in diverse leadership styles. The influence of those styles plays a significant role in subordinates' effectiveness and an organisation's performance (Alimo-Metcalfe, 2013; Laohavichien et al., 2009). Furthermore, the dramatic change in the cultural, economic, historical, and political perspective forces to demand new leadership behaviours. Simply that, the style and skill that leaders acquired previously may not work in the current changes in our daily lifetime (Miao, Newman, Schwarz, \& Xu, 2014; Van Wart, 2013).

Moreover, the significance of leadership is deliberate in global awards. Accreditation institutions such as The Malcolm Baldrige National Quality Award (MBNQA) and Joint Commission International (JCI) consider leadership an essential and significant part of their accreditation process. Deming and Juran, two well-known quality gurus, emphasise the importance of top management support for the successful overall organisational performance (Alharbi \& Yusoff, 2012; Hirtz, Murray, \& Riordan, 2015). Deming's 14 Points clarify the significance of leadership support during the implementation of quality management practices. Furthermore, the religious literature has a significant additional input for leadership. For instance, considering the Islamic literature, Almighty Allah and the Prophet Mohammad (PBUH) and his followers highlight the significance of leadership on many occasions (Alshammari, 2014). Almighty Allah states in the Holy Qur'an, "And We appointed, from among them, leaders, giving guidance under Our command, so long as they persevered with patience and continued to have faith in Our Signs" (Qur'an, 32:24). Prophet Mohammad (PBUH advises 
that "when three people on a journey, they should appoint one of them as their commander ("Islam the modern religion," 1984).

Consequently, it's with no doubt that leadership is considered as the heart and an essential part of any institution, whatever its size and type (Alblooshi et al., 2020; Ford et al., 2021; Grinerud, Aarseth, \& Robertsen, 2021; Alharbi \& Yusoff, 2012; Firth-Cozens \& Mowbray, 2001; Loulas, 2014; Spinks \& Wells, 1995). Nevertheless, there is an ambiguity and misinterpretation of three terms related to leadership. These are leadership style, leadership behaviour, and leadership traits. This paper aims to clarify this misunderstanding of the three terms by discussing the concept of leadership, and the three terms align with leadership.

\section{THE THEORETICAL GAP}

The concept of leadership is regularly used in a collocated pair of words, such as educational leadership and democratic leadership. (Ford et al., 2021). So it called in linguistics a "collocation", which is a series of words or terms that co-occur more often than expected by chance to carry a different meaning in the same domain. In leadership literature, authors use "leadership word collocation" to express what they will focus on and discuss. The three most contradicted leadership collocations are "leadership style", "leadership behaviour", and "leadership traits". Some other examples of leadership collocations are "leadership skills", "leadership qualities", "leadership quotes", "leadership approaches", and others. Nevertheless, style, behaviour, and traits are the most common words aligned with leadership.

For example, (Huang, 1994) argue that the style and behaviour of leadership used as synonymous. The main goal of both leadership style and behaviour is the action of such a leader. In this regard, style and behaviour consider as an action that a leader performs. Additionally, (Freedman, 2016) describes that some behaviours define as a leadership style in their book. The leader uses both behaviour and style similarly when adopts the two concepts. Therefore, behaviour and style have no difference, and the two words will have one meaning either when used together or separately.

On the other hand, others used leadership style and behaviour contrarily (Bavik, Shao, Newman, \& Schwarz, 2021; Ford et al., 2021; Sousa \& van Dierendonck, 2021; Ahmed, Nawaz, \& Khan, 2016; Bolden, Gosling, Marturano, \& Dennison, 2003; France, 2008). They claimed that a style categorises as a combination of different patterns of behaviours. Style is considered an act of action. In this regard, they claim that a behaviour of a leader is what is discussed in the literature of the behavioural theories and a style comprise for many behaviours. This shows that the use of style or behaviour either separately or together in one sentence will totally mean a different set of definition.

Although the above discussion shows two clear augments regarding leadership style and behaviour, other researchers used leadership style and behaviour ambiguity (Joseph, Dhanani, Shen, McHugh, \& McCord, 2015). Therefore an interpretation of the three contradicted terms is needed. To deeply understand the ambiguity of this study, a discussion of the leadership theories perhaps will be broadening the way to differentiate between the three contradicted terms. This discussion aims to answer the below research questions.

1 Are there any differences between leadership style, leadership behaviour, and leadership traits?

2 What is the definition of the three contradicted terms?

3 Can one of the three contradicted terms represent the remaining terms?

\section{LITERATURE REVIEW}

\section{What is the Definition of Leadership?}

The literature highlights the complexity of leadership and its definition in modern organisations as there are considerable numbers of stakeholders involved in the leading paradigm (Ali, 2012; Latham, 2014; Stewart, 2006; Vilegi-Peters, 2010). Although there is no such consent on the definition of leadership, it has nevertheless, that the broader meaning of leadership involves numerous processes which start from creating a vision to translating this vision into tangible achievement goals (Ali, 2012; Stewart, 2006; Ulle \& Kumar, 2014; Vilegi-Peters, 2010). Therefore, leadership is defined as a leader who influences subordinates to achieve common objectives in organisations (Ali, 2012; France, 2008; Hirtz et al., 2015). In addition, James Mac Gregor Burns (1978), the founder of transformational and transactional leadership style, emphasises this influence of leadership on subordinates. He states that "Leadership as leaders inducing followers to act for certain goals that represent the values and the motivations - the wants and needs, the aspirations and expectations - of both leaders and followers ' (Burns, 1978).

Considering a linguistics perspective, the lexical definition of the word leader as a noun in the old English lædere is "one who leads, one first or most prominent," agent" noun from lædan "to guide, conduct (udi, 1999; Blackburn, 2005).

On the other hand, the lexical definition of leadership as a noun is "the quality and ability that makes a person in the position of being a leader" (oxford dictionary, Cambridge dictionary). The leadership origin was in 1821. Position of a leader, command, from leader + ship. Sense extended by the late 19th century to "characteristics necessary to be a leader, capability to lead." (Audi, 1999; Blackburn, 2005) 


\section{History and Theories of Leadership}

The concept of leadership has existed since early human history (Vilegi-Peters, 2010). A fundamental discussion in the history of leadership theories is the correlation between a leader's behaviour and its consequences by considering situations that moderate this relationship (Wofford, Goodwin, \& Whittington, 1998). However, the concept and background of leadership have changed over time (Hewitt, Dahlen, Hartz, \& Dadich, 2021). In the early times, the concept focused on production-oriented leadership (Kosicek, Soni, Sandbothe, \& Slack, 2012) and on the tasks and process-based involved in leadership (Gordon, 2009) instead of considering the human factors (Gordon, 2009; Kosicek et al., 2012). Then the concept of leadership developed since the first empirical study that was published a study in 1904. It shifted gradually from behaviour, traits, and contingency approaches to our current leadership understanding (Bass \& Stogdill, 1990; Lakshman, 2006).

As leadership history and theories are extremely rich, this paper will discuss the three most used categorisations of leadership theories (Bensimon, Neumann, \& Birnbaum, 1989; Huang, 1994). These are the traits, behavioural, and contingency theory of leadership.

The concentration of leadership theories in the early periods was on the traits of leadership. The traits theories of leadership resulted from developing the Great Man Theory in the $19^{\text {th }}$ century that focuses on the traits with which a leader is born with (Bolden et al., 2003). This type of research takes advantage of those traits that the leader is born with to determine the successful traits of leadership. Traits theories attempted to answer the question of what attributes are great leaders born with and differentiate a leader from a follower. However, no such conformity was found that could identify the effective leadership traits as many traits of successful leadership were suggested (Bolden et al., 2003; Freedman, 2016; Horner, 1997; Huang, 1994). To reach an agreement on effective leadership traits, Stogdill (1974) suggested the most common leadership traits and skills which are listed in Table 1.

Table 1: Lists of leadership traits and skills identified by Stogdill in 1974

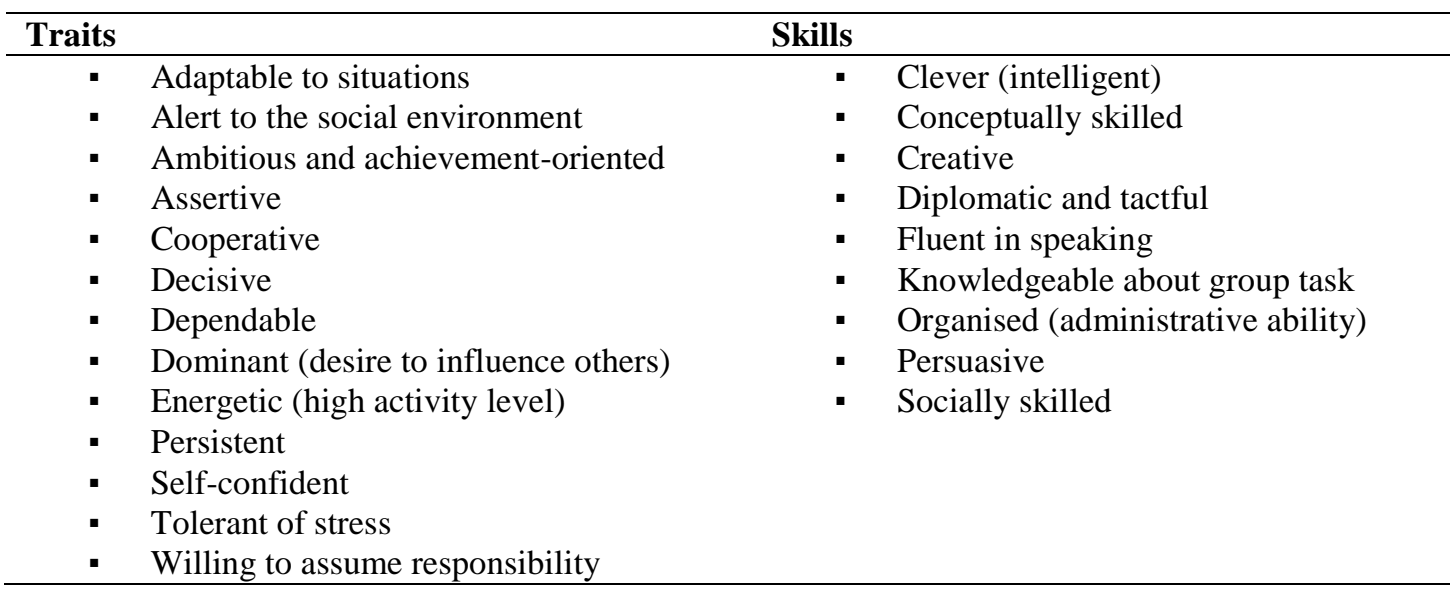

Although the traits approach is still used in the military sector Bolden et al. (2003), a significant criticism worth mentioning for this type of research is that the environmental Freedman (2016) and situational aspects which considered vital determinants of effective leadership were not considered (Horner, 1997; Stogdill, 1974). These aspects are covered by other leadership theories, such as the behavioural and contingency theory of leadership.

As a result of the limitation of traits theories, the human relations approach emerged in the 1940s, and the book The Human Side of Enterprise was published in 1960 by Douglas McGregor's. This shifted our understanding of leadership research toward a behavioural based concept of leadership called behavioural theories (Bolden et al., 2003; Huang, 1994). These theories do not focus on the leader's traits but actions regarding their influence toward their subordinates (Freedman, 2016; Horner, 1997). One significant result of these theories was to change the view of the traits theories that claim great leaders are born to more sophisticated views of leaders as behaviours that can be taught (Horner, 1997; Huang, 1994). Because of the emergence of these theories, many studies conducted to examine behavioural aspects practically. Two well-known studies conducted by Michigan and Ohio State University reveal diverse dimensions categorised into four types (Freedman, 2016; Horner, 1997; Huang, 1994). These categorisations suggested by Freedman (2016) are task concern (production-oriented), concern for people (employee centred), directive leadership (authoritarian or autocratic), and participative leadership (democratic). Other categorisations worth mentioning are given by Derue, Nahrgang, Wellman, and Humphrey (2011), as shown in Table 2.

Table 2: Behavioural dimensions of leadership (Derue et al., 2011)

\begin{tabular}{llll}
\hline Task-oriented & Relational-oriented & Change-oriented & Passive Leadership \\
\hline
\end{tabular}




\begin{tabular}{llll}
\hline - Initiating & $\bullet$ Consideration & $\bullet$ Transformational & - Management by \\
structure & Empowerment & - Charismatic, & exception-passive \\
- Contingent & -Participative & inspirational & \\
reward & -Developing & & \\
- Management by & - Enabling & \\
exception-active & - Servant leadership & \\
- Boundary & & \\
spanning & & \\
- Directive & & \\
\hline
\end{tabular}

Although the behavioural theories of leadership have expanded our understanding of leadership theories, it has limitations that prevent it from being a universal leadership style. Huang (1994) and Freedman (2016) listed limitations that mainly concern the environmental and situational aspects ignored in behavioural theories. Therefore, a shift toward contingency theories were suggested (Bolden et al., 2003; Freedman, 2016; Huang, 1994).

While the behavioural theories concentrated on the internal behaviour that can be learned and developed, contingency theories are about the external factors that an effective leader needs to deal with (Bolden et al., 2003; Huang, 1994). This concept started in the 1960s by assuming that effective leadership comprises a diverse combination of leader's traits and behaviours that deal and lead dependently according to each situation. Therefore, the situation factors play a vital role in deciding what leadership style a leader may practice. In addition, the contingency theories assume that the style that a leader uses in each situation is based on sort factors, including the nature of the task, subordinates and leaders qualities, subordinates maturity, the organisation, and other environmental factors (Bolden et al., 2003; Freedman, 2016; Huang, 1994). Numerous theories developed along with the history of leadership, such as the Fielder Contingency Model in 1964, Path-Goal Theory by House in 1971, Hersey Blanchard Model in 1988 until the current leadership theories such as transformational and transactional.

Knowing the history and definition of leadership theories will perhaps broaden the understanding of leadership to facilitate the interpretation and differentiate between the three contradicted terms.

\section{METHODOLOGY}

This paper use Dubé and Paré (2003) method to implement a systematic content analysis for the chosen previous published literature. It has at the beginning selected a keyword that identifies the appropriateness of the matched keyword to the goal of the study (Sanil et al., 2015, Ramakrishnan et al., 2016, Alsolami et al. 2016, Alsolami et al. 2017). Then, the relevant online databases are determined, which include Scopus, Science Direct, Web of Science, Emerald, and Google Scholar. Moreover, the chosen articles categorised into three different parts. Firstly, leadership part, secondly, behavioural, traits and style theories part. The third part is a discussion of both concepts. Finally, recording the findings after the assessment of articles.

\section{RESULT}

The result of this study discloses three contradictory terms. Those are leadership style, leadership behaviour, and leadership traits. To expand the study result and conclude the argument of the three contradicted terms, a definition of those terms will be discussed from both the management and linguistic perspective. This discussion of each of the three contradicted terms and their definition will respond to this paper's questions.

\section{Leadership Traits}

Leadership traits are the attributes of a leader that describe the common characteristics and personality among leaders and those in a position of authority. Typically, leadership traits encompass physical, emotional, social, and intellectual characteristics. In addition, they represent characteristics such as the ability to communicate effectively and motivate others, self-confidence, ambition, and high energy. These traits represent the individual characteristics that go into creating a specific leadership style (Bolden et al., 2003; Freedman, 2016)

From a linguistics perspective, the lexical definition of traits as a noun is a particular quality in personality or a distinguishing feature of personal nature. This specific characteristic can produce a particular type of behaviour and biologically meaning. A trait is also a characteristic of an organism that is passed from parent to child. The synonyms of the word trait are feature and characteristic. (Audi, 1999; Blackburn, 2005)

\section{Leadership Behaviour}

The behavioural theories of leadership don't concentrate on the traits of leaders; instead, they study the activities of leaders to identify their behavioural patterns. Those behavioural patterns differ from leadership traits because those behavioural patterns can be learned and developed. Furthermore, integrating those behavioural patterns builds diverse themes that create a leadership style such as transformational, transactional, democratic, and others. The leader behaviour is the best predictor of leadership influences and the best determinant of leadership success. Therefore, the 
behavioural theories of leadership define a leader's behaviour that leads subordinates to reach the organisation goals. (Freedman, 2016; Horner, 1997; Huang, 1994).

From a linguistics perspective, the lexical definition of behavioural as an adjective comes from the verb behave, which is to do things in a particular way. The synonym of the word behavioural is act (Audi, 1999; Blackburn, 2005).

\section{Leadership Style}

A style perhaps defines from an architecture perspective as the design and way things have been combined and presented (Goodman, 1975). On the other hand, leadership style is the leader characteristic and approach of directing and motivating employees (Kendra, 2018; Newstrom, Davis, \& Pierce, 1993; Zaccaro, Green, Dubrow, \& Kolze, 2018). However, the terms style and behaviour are confusing, as they usually treat as synonymous words and interchangeable concepts (Huang, 1994). To conclude, leadership style combines both traits and behavioural theories that assist in constructing an individual style; this personal style aims to create an approach that influences followers for organisational success and guides future leaders.

From a linguistics perspective, the lexical definition of style as a noun is the way of doing something. The word origin: Middle English (denoting a stylus, also a literary composition, an official title, or a characteristic manner of literary expression. The synonym of the word style is the manner (Audi, 1999; Blackburn, 2005).

\section{DISCUSSION}

The above discussion highlight how significant is the integration of the three contradictory terms with leadership. The notion of integration is supported by a study done by Zaccaro et al. (2018) that reviews several leader individual differences articles through The Leadership Quarterly Journal. The study reveals a need for integrative research that considers leaders individual differences that comprise many factors such as leadership traits, behaviour, and style.

Following the notion of integrating the three contradiction terms leads to an additional investigation into combining this integration, responding to the questions inquiries about how one of the three contradiction terms represent by one phrase or word. Responding to such a question would be by defining what the driving force for leadership was. The previous discussion reveals that leadership style is the consequence of many factors that include traits and behavioural (Kendra, 2018; Newstrom, Davis, \& Pierce, 1993; Zaccaro et al., 2018).

Although this discussion responds to this paper question to some extent, it is still to discover how the style varies between leaders. Each leader perhaps will demonstrate some of the traits and behaviours. Nevertheless, how they will act/do is different. These are the hidden aspects behind the style. For instance, a chief in a kitchen can make different food from diverse integrated than other chiefs who have the same integration. It's not only to this extent, they can both do one set of dishes with the same sets of integration, but each of them will have a different style. Another example is painter artists. Those artists can draw one picture, but each of them has its style of painting.

Therefore, both traits and behavioural build leadership, but how leaders will lead will depend on their style. This individual style aims to create an approach that influences followers for organisational success and guides future leaders (Kendra, 2018; Newstrom, Davis, \& Pierce, 1993; Zaccaro et al., 2018). Figure 1. Conceptual Framework demonstrates how the three contradicted terms are related.

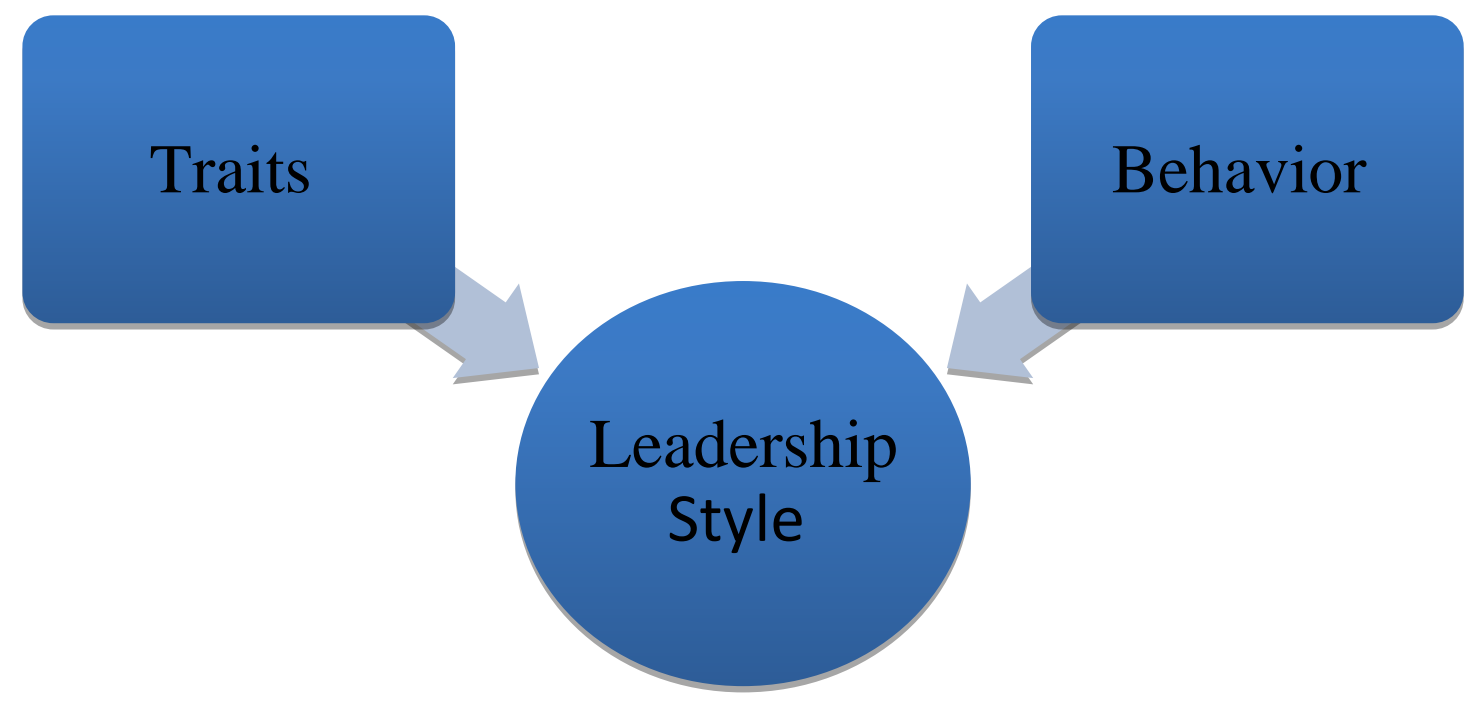

Figure 1: Conceptual Framework for leadership 


\section{CONCLUSION}

Leadership is one of the riches and complex concepts in management theories. Since numerous stakeholders are involved in the leading paradigm, it's regularly used with a collocated pair of words. This paper attempts to discuss the ambiguity and contradiction of leadership, emphasising the three most used terms with leadership: leadership style, leadership behaviour, and leadership traits. This paper interprets leadership and the three contradicted terms to reveal the misuse of those three terms with leadership. Although this paper covers its intended about the three contradiction terms, future research would advance this research more practically through implementing methodological and analytical strategies. This is one of the limitations of this study where a quantitative and qualitative inquiry would enhance the result of this paper.

\section{AUTHOR'S CONTRIBUTION}

Wael Ibrahim Alsarrani ${ }^{1 *}$ : Main Author. Ahmad Jusoh ${ }^{2}$ : Supervisor for the complete study. Ayman Ahmed Alhaseri ${ }^{3}$, contribute to add the linguistics part for the definition of the three terms of leadership: leadership style, leadership behaviour, and leadership traits. Conduct literature review for the three terms. Amani Almeharish ${ }^{4}$ : Principle investigator for data collection proofreading, referencing, general guiding for the article.

\section{REFERENCES}

1 Audi, R. (1999). The Cambridge dictionary of philosophy.The Cambridge Dictionary of Philosophy. New York: Cambridge University Press.

2 Ahmed, Z., Nawaz, A., \& Khan, I. (2016). Leadership Theories and Styles: A Literature Review. Journal of Resources Development and Management, 16(1), 1-7.

3 Alblooshi, M., Shamsuzzaman, M., \& Haridy, S. (2020). The relationship between leadership styles and organisational innovation. European Journal of Innovation Management, 24(2). https://doi.org/10.1108/EJIM11-2019-0339

4 Alharbi, M., \& Yusoff, R. Z. (2012). Leadership styles, and their relationship with quality management practices in public hospitals in Saudi Arabia. International Journal of Economics \& Management Sciences, $1(10), 59-67$.

5 Ali, A. (2012). Leadership and its Influence in Organizations-A Review of Intellections. International Journal of Learning and Development, 2(6), 73-85. https://doi.org/10.5296/ijld.v2i6.2690

6 Alimo-Metcalfe, B. (2013). A critical review of leadership theory. The wiley-blackwell handbook of the psychology of leadership, change, and organizational development, 13-47. https://doi.org/10.1002/9 781118326404.ch2

7 Alshammari, F. (2014). Nursing leadership in the Ministry of Health hospitals of Saudi Arabia.

8 Alsolami, B., Embi, M. R., \& Enegbuma, W. I. (2016). The influence of personal factors on Hajj crowd perception among African Pilgrim Group in Mina. Indian Journal of Science and Technology, 9(46),1-9. https://doi.org/10.17485/ijst/2016/v9i46/107123

9 Bass, B. M., \& Stogdill, R. M. (1990). Handbook of leadership (Vol. 11): New York: free press.

10 Bavik, Y. L., Shao, B., Newman, A., \& Schwarz, G. (2021). Crisis leadership: A review and future research agenda. The Leadership Quarterly, 101518. https://doi.org/10.1016/j.leaqua.2021.101518

11 Bensimon, E., Neumann, A., \& Birnbaum, R. (1989). Making sense of administrative leadership: The" L" word in higher education (ERIC Document Reproduction Service No. ED316074).

12 Blackburn, S. (2005). The Oxford dictionary of philosophy: OUP Oxford.

13 Bolden, R., Gosling, J., Marturano, A., \& Dennison, P. (2003). A review of leadership theory and competency frameworks. Centre for Leadership Studies, University of Exeter.UK.

14 Burns, J. M. (1978). Leadership. New York: Harper \& Row.

15 Chemers, M. (2014). An integrative theory of leadership: Psychology Press. https://doi.org/10.4324/9 $\underline{781315805726}$

16 Derue, D. S., Nahrgang, J. D., Wellman, N., \& Humphrey, S. E. (2011). Trait and behavioral theories of leadership: An integration and meta-analytic test of their relative validity. Personnel psychology, 64(1), 7-52. https://doi.org/10.1111/j.1744-6570.2010.01201.x

17 Dinh, J. E., Lord, R. G., Gardner, W. L., Meuser, J. D., Liden, R. C., \& Hu, J. (2014). Leadership theory and research in the new millennium: Current theoretical trends and changing perspectives. The Leadership Quarterly, 25(1), 36-62. https://doi.org/10.1016/j.leaqua.2013.11.005

18 Dionne, S. D., Gupta, A., Sotak, K. L., Shirreffs, K. A., Serban, A., Hao, C., . . Yammarino, F. J. (2014). A 25-year perspective on levels of analysis in leadership research. The Leadership Quarterly, 25(1), 6-35. https://doi.org/10.1016/j.leaqua.2013.11.002

19 Dóci, E., Stouten, J., \& Hofmans, J. (2015). The cognitive-behavioral system of leadership: cognitive antecedents of active and passive leadership behaviors. Frontiers in psychology, 6, 1344. https://doi.org/10.3389/fpsyg.2015.01344

20 Dubé, L., \& Paré, G. (2003). Rigor in information systems positivist case research: current practices, trends, and recommendations. MIS quarterly, 597-636. https://doi.org/10.2307/30036550 
21 Firth-Cozens, J., \& Mowbray, D. (2001). Leadership and the quality of care. Quality in health care, 10 (suppl 2), ii3-ii7. https://doi.org/10.1136/qhc.0100003

22 France, S.-H. (2008). Leadership Theories: Toward a Relational Model. Retrospective Exam, EXD-66909 for the Ad Hoc doctoral programme of administrative sciences, Université Laval, Québec.

23 Freedman, A. M. (2016). The Wiley-Blackwell handbook of the psychology of leadership, change and organizational development: John Wiley \& Sons.

24 Ford, J., Ford, L., \& Polin, B. (2021). Leadership in the Implementation of Change: Functions, Sources, and Requisite Variety. Journal of Change Management, 21(1), 87-119. https://doi.org/10.1080/146 97017.2021.1861697

25 Goodman, N. (1975). The status of style. Critical Inquiry, 1(4), 799-811. https://doi.org/10.1086/447816

26 Gordon, V. (2009). Early twentieth century management theories and models that shaped twenty-first century school leadership. Journal of Philosophy \& History of Education, 59, 67-70.

27 Grinerud, K., Aarseth, W. K., \& Robertsen, R. (2021). Leadership strategies, management decisions and safety culture in road transport organizations. Research in Transportation Business \& Management, 100670. https://doi.org/10.1016/j.rtbm.2021.100670

28 Hewitt, L., Dahlen, H. G., Hartz, D. L., \& Dadich, A. (2021). Leadership and management in midwifery-led continuity of care models: A thematic and lexical analysis of a scoping review. Midwifery, 102986. https://doi.org/10.1016/j.midw.2021.102986

29 Hirtz, P. D., Murray, S. L., \& Riordan, C. A. (2015). The Effects of Leadership on Quality. Engineering Management Journal, 19(1), 22-27. https://doi.org/10.1080/10429247.2007.11431718

30 Horner, M. (1997). Leadership theory: past, present and future. Team Performance Management: An International Journal, 3(4), 270-287. https://doi.org/10.1108/13527599710195402

31 Huang, C.-C. (1994). Assessing the leadership styles and total quality leadership behaviors of presidents of four-year universities and colleges that have implemented the principles of Total Quality Management. The Ohio State University.

32 Islam the modern religion. (1984, 14/09/2016). Retrieved from http://www.themodernreligion.com/ basic/charac/muslim organise.html

33 Joseph, D. L., Dhanani, L. Y., Shen, W., McHugh, B. C., \& McCord, M. A. (2015). Is a happy leader a good leader? A meta-analytic investigation of leader trait affect and leadership. The Leadership Quarterly, 26(4), 557-576. https://doi.org/10.1016/j.leaqua.2015.04.001

34 Kendra, C. (2018). Leadership Styles and Frameworks You Should Know. Retrieved from https://www.ver ywellmind.com/leadership-styles-2795312

35 Khanin, D. (2007). Contrasting Burns and Bass: Does the transactional-transformational paradigm live up to Burns' philosophy of transforming leadership? Journal of Leadership Studies, 1(3), 7-25. https://doi.org/10.1002/j1s.20022

36 Kosicek, P. M., Soni, R., Sandbothe, R., \& Slack, F. (2012). Leadership styles, industry fit, and quality focus. Paper presented at the Competition Forum.

37 Lakshman, C. (2006). A theory of leadership for quality: Lessons from TQM for leadership theory 1. Total Quality Management \& Business Excellence, 17(1), 41-60. https://doi.org/10.1080/14783360500249729

38 Laohavichien, T., Fredendall, L. D., \& Cantrell, R. S. (2009). The effects of transformational and transactional leadership on quality improvement. The Quality Management Journal, 16(2), 7. https://doi.org/10.1080/10686967.2009.11918223

39 Latham, J. R. (2014). Leadership for quality and innovation: Challenges, theories, and a framework for future research. Latham, JR (2014). Leadership for quality and innovation: Challenge, theories, and a framework for future research. Quality Management Journal, 21(1), 5. https://doi.org/10.1080/10686967.2014.11918372

40 Loulas, N. (2014). How leadership theory can contribute in quality improvement efforts, by influencing change, teamwork and goal management, KTH Royal Institute of Technology, Dissertation. Complete the reference

41 Miao, Q., Newman, A., Schwarz, G., \& Xu, L. (2014). Servant leadership, trust, and the organizational commitment of public sector employees in China. Public Administration, 92(3), 727-743. https://doi.org/10.1111/padm.12091

42 Michel, J. W., Wallace, D. L., \& Rawlings, R. A. (2013). Charismatic leaders: the role of admiration and system justification. Leadership \& Organization Development Journal, 34(5), 469-487. https://doi.org/10.1 108/LODJ-11-0099

43 Newstrom, J. W., Davis, K., \& Pierce, J. L. (1993). Organizational behavior: Human behavior at work.

44 Poon Teng Fatt, J. (2000). Charismatic leadership. Equal Opportunities International, 19(8), 24-28. https://doi.org/10.1108/02610150010786184

45 Ramakrishnan, S., Hishan, S. S., Shahabuddin, A. S. M., \& Kanjanapathy, M. (2016). The Role of Corporate Social Responsibility in Flood Mitigation among the Listed Insurance Companies in Malaysia. International Review of Management and Marketing, 6(4S), 86-90

46 Sanil, H. S., \& Ramakrishnan, S. (2015). Communicating the corporate social responsibility on the company website: A study conducted on worldwide responsible accredited production certified apparel manufacturers in India. International Journal of Economics and Financial Issues, 5, 52-56. 
47 Sousa, M., \& van Dierendonck, D. (2021). Serving the need of people: the case for servant leadership against populism. Journal of Change Management, 1-20. https://doi.org/10.1080/14697017.2021.1917494

48 Spinks, N., \& Wells, B. (1995). Quality communication: a key to quality leadership. Training for Quality, 3(2), 14-19. https://doi.org/10.1108/09684879510087486

49 Stewart, J. (2006). Transformational leadership: An evolving concept examined through the works of Burns, Bass, Avolio, and Leithwood. Canadian Journal of Educational Administration and Policy, 54, 1-29.

50 Stogdill, R. M. (1974). Handbook of leadership: A survey of theory and research: Free Press.

51 Uhl-Bien, M. (2021). Complexity Leadership and Followership: Changed Leadership in a Changed World. Journal of Change Management, 1-19. https://doi.org/10.1080/14697017.2021.1917490

52 Ulle, R. S., \& Kumar, A. S. (2014). A Review on Total Quality Leadership in TQM Practices-Industrial Management and Organizations. International Journal of Emerging Research in Management \&Technology, 3(5), 152-155.

53 Van Wart, M. (2013). Lessons from leadership theory and the contemporary challenges of leaders. Public Administration Review, 73(4), 553-565. https://doi.org/10.1111/puar.12069

54 Vilegi-Peters, D. (2010). The impact of effective leadership on quality: The role of leadership in managing quality initiatives in health care. Available from Dissertations \& Theses database( 305245109 ).

55 Wofford, J., Goodwin, V. L., \& Whittington, J. L. (1998). A field study of a cognitive approach to understanding transformational and transactional leadership. The Leadership Quarterly, 9(1), 55-84. https://doi.org/10.1016/S1048-9843(98)90042-X

56 Zaccaro, S. J., Green, J. P., Dubrow, S., \& Kolze, M. (2018). Leader individual differences, situational parameters, and leadership outcomes: A comprehensive review and integration. The Leadership Quarterly, 29(1), 2-43. https://doi.org/10.1016/j.leaqua.2017.10.003 